\title{
Impedance Converter Device
}

National Cancer Institute

\section{Source}

National Cancer Institute. Impedance Converter Device. NCI Thesaurus. Code C49998.

A device designed to change the resistance of an electric circuit. 